\title{
Emission of Fine Particulate Matter and Nitrogen Dioxide from Incense Burning in Shrines, Chiang Mai, Thailand
}

\author{
S. Bootdee and S. Chantara
}

\begin{abstract}
The inhalation of fine particles $\left(\mathbf{P M}_{2.5}\right)$ and nitrogen dioxide $\left(\mathrm{NO}_{2}\right)$ has been associated with health problems. Incense burning is an important indoor source of these pollutants. This research aims to measure $\mathbf{P M}_{2.5}$ and $\mathrm{NO}_{2}$ emitted from incense burning in shrines on special occasions and during normal periods to assess the indoor air quality changes. $\mathbf{P M}_{2.5}$ samples were collected on Teflon filters using a mini volume air sampler set up inside the shrines, while $\mathrm{NO}_{2}$ samples were collected by tube type passive samplers, set up both indoors and outdoors. When special events were compared with normal occasions, the mean $\mathbf{P M}_{2.5}$ concentrations obtained from 8 and 24 hrs were significantly different $(p<0.05)$. Moreover, their concentrations were significantly higher on Chinese New Year than on other special occasions. In the case of $\mathrm{NO}_{2}$, the concentrations were not different among a variety of special occasions, but were higher than the values measured during the normal periods. Moreover, $\mathrm{NO}_{2}$ concentrations were not found to be significantly different when the indoor and the outdoor values were compared. The values of $\mathrm{PM}_{2.5}$ and $\mathrm{NO}_{2}$ concentrations at both shrines were highest during the Chinese New Year. The main reason for this was clearly the number of visitors, which was related with the amount of incense being burned. Concentrations of $\mathrm{NO}_{2}$ and $\mathrm{PM}_{2.5}$ were well correlated $(r=0.580-0.779)$ in every occasion. It can be concluded that the amount of incense being burned played a significant role in pollutant emissions and the indoor air quality.
\end{abstract}

Index Terms $-\mathbf{P M}_{2.5}$, nitrogen dioxide, incense burning, indoor air quality.

\section{INTRODUCTION}

Particulate matter (PM) is of great importance due to its adverse effects on human health. Coarse particles $\left(\mathrm{PM}_{10}\right.$, particles with an aerodynamic diameter of $10 \mu \mathrm{m}$ or less) and fine particles $\left(\mathrm{PM}_{2.5}\right.$, particles with an aerodynamic diameter of $2.5 \mu \mathrm{m}$ or less) are often used as important indicators to characterize the mortality and health risk from lung cancer and cardiopulmonary deaths. However, the mortality rates and health risks were found to be greater for $\mathrm{PM}_{2.5}$ than $\mathrm{PM}_{10}$ [1].

$\mathrm{PM}_{2.5}$ is formed from the gas and condensation of high-temperature vapors during the combustion processes including forest fires or residential wood fires, the burning of fossil fuels in motor vehicles, furnaces, boilers, and heaters and certain industrial processes. Secondarily, fine particles

Manuscript received August 16, 2001; revised October 3, 2013.

Susira Bootdee is with the Environmental Science Program, Faculty of Science, Chiang Mai university, Chiang Mai, 50200, Thailand (e-mail: b.susira@gmail.com).

Somporn Chantara is with the Environmental Chemistry Research Laboratory (ECRL), Chemistry Department and the Environmental Science Program, Faculty of Science, Chiang Mai university, Chiang Mai, 50200, Thailand (e-mail: somporn.chantara@cmu.ac.th). are created when chemicals react in the atmosphere and grow through particle-particle or gas-particle interactions. $\mathrm{PM}_{2.5}$ is believed to pose the greatest health risks because they can go as deep as the alveoli [2]. However, Fierro [1] reported that $\mathrm{PM}_{2.5}$ was associated with a $36 \%$ increase in deaths from lung cancer and $26 \%$ increase in cardiopulmonary deaths and these risks are even greater for people over the age of 65 . The increased levels $\mathrm{PM}_{2.5}$ of each $10 \mu \mathrm{g} / \mathrm{m}^{3}$ were associated with approximately a $4 \%, 6 \%$, and $8 \%$ increase in all causes of cardiopulmonary and lung cancer mortality, respectively [3].

Nitrogen dioxide $\left(\mathrm{NO}_{2}\right)$ is also an important indicator of air pollution. It is the most toxic form of nitrogen oxide $\left(\mathrm{NO}_{\mathrm{X}}\right)$ generated from motor vehicles or traffic, electric utilities and indoor combustion sources. Indoor air studies have provided evidence of the effects on the respiratory symptoms of infants at $\mathrm{NO}_{2}$ concentrations below $40 \mu \mathrm{g} / \mathrm{m}^{3}$. These associations cannot be completely explained by co-exposure to PM, but it has been suggested that other components in the mixture (such as organic carbon and nitrous acid vapours) might explain part of the observed association [4]. The inhalation of nitrogen dioxide serves as a strong respiratory irritant, reduces resistance against respiratory infections, alters the lung function in asthmatics and enhances bronchial responsiveness to allergens.

Incense burning has been a common practice in many countries. Buddhism and Taoism are the major religions in East Asia in such places as China, Thailand and Taiwan. Incense burning is a daily practice involved in worship at religious ceremonies and is also a tradition that acknowledges paying respect to one's ancestors [5]. Besides, incense and joss paper burning are an important ceremonial practice for deity worshipping in these religions especially in China and Taiwan.

Burning of incenses emits a lot of gaseous and particulate pollutants. Lee and Wang [6] reported the characteristically emissions of air pollutants from incense burning in a large environmental test chamber. Three types of incense were compared including tradition, aromatic and church incense. The target pollutant included PM10 and PM2.5, volatile organic compounds (VOCs), carbon monoxide (CO), carbon dioxide $\left(\mathrm{CO}_{2}\right)$, nitrogen oxide $\left(\mathrm{NO}_{\mathrm{X}}\right)$ and methane $\left(\mathrm{CH}_{4}\right)$. The particulate matter and $\mathrm{CO}$ emitted from all the incense type significantly exceeded the Recommended Indoor Air Quality objectives for Office Building and Public Places in Hong Kong (HKIAQO). It was found that the VOCs emitted sequence was aromatic incense> traditional incense $>$ church incense. The emission factors of PM2.5 from incense burning varied between $0.4-44 \mathrm{mg} / \mathrm{g}$ [7] to $5-56 \mathrm{mg} / \mathrm{g}$ [8]. The study from Taiwan [9] showed that concentrations of indoor suspended particulate $\left(\mathrm{PM}_{2.5}, \mathrm{PM}_{2.5-10}\right.$ and $\left.\mathrm{PM}_{10}\right)$ increased during the time when pilgrims appeared at the incense 
burning period. The average $\mathrm{PM}_{2.5}, \mathrm{PM}_{2.5-10}$ and $\mathrm{PM}_{10}$ concentrations were $63.3,26.5,89.7 \mu \mathrm{g} / \mathrm{m}^{3}$, respectively. The $\mathrm{PM}_{2.5} / \mathrm{PM}_{10}$ ratios during the incense burning period ranged between 31.2-87.4\% with the averaged of $69.6 \pm 12.3 \%$. Total suspended particulate (TSP) and particulate - bound total PAHs (21 PAHs) from inside and outside of a Taiwanese temple were also monitored by Lin et al. [10]. The average TSP concentration in the indoor was $790 \mu \mathrm{g} / \mathrm{m}^{3}$, which was 3-11 times higher than the outdoors $(72.5 \mu \mathrm{g} / \mathrm{m} 3)$. The average PAH concentration of the inside air $(8,888 \pm$ $3,598 \mathrm{ng} / \mathrm{m}^{3}$ ) was approximately 19 times higher than the outdoors $\left(468 \pm 156 \mathrm{ng} / \mathrm{m}^{3}\right)$. Incense burning is found to be a significant source of PAHs, heavy metals, particulate matters, greenhouse gases ( $\mathrm{CO} 2$ and $\mathrm{CH} 4)$ and VOCs [2], [11], [12].

Exposure to incense smoke may be associated with many adverse health effects including cancer, respiratory morbidity, central nervous system damage and lung irritation [2], [12], [13]. Numerous studies related to inhalation epidemiology have shown a positive association between ambient PMs - bound PAHs concentrations and adverse health effects. Navasumrit et al. [13] conducted the study in Thailand by comparing two studied subject groups. Air particulate samples were collected by using personal air sampling from temple workers $(n=40)$ and control group $(n=$ $25)$. It was found that the temple workers were exposed to relatively high level of benzene $\left(45.90 \mu \mathrm{g} / \mathrm{m}^{3}\right), 1,3$-butadiene $\left(11.29 \mu \mathrm{g} / \mathrm{m}^{3}\right)$ and PAHs $\left(19.56 \mathrm{ng} / \mathrm{m}^{3}\right)$, which were significantly higher than those of control workers $(p<0.01)$. These results indicated that exposure to carcinogens emitted from incense burning may increase health risk for the development of cancer in temple workers. The similar study was carried out in Taiwan, but with more sample types. PM10 samples were collected by using personal collection sampler during pilgrim day (the first and fifteenth day of each lunar month) and normal days (all other days) from the temple workers. The samples were analyzed for PAHs. It was found that the total PAHs (t-PAHs) and carcinogenic PAHs (car-PAHs) on pilgrim days were higher than those on normal days. Mean concentrations of urinary 1-hydroxypyrene (1-OHP) in the pre-shift and post-shift workers of the temples on normal days were 1.20 and 1.61 $\mu \mathrm{g} / \mathrm{g}$ creatinine, respectively. However, the post-shif concentrations of 1-OHP found in the temple worker on pilgrim days were all higher than those on normal days. In other words, an increase of unit concentration of urinary 1-OHP would lead to an approximate 32-fold increase of cancer risk for the workers of the temples [14]. Chiang and Liao [12] reported the assessment of human exposure to airborne PMs and PAHs from heavy incense burning in temples using a mechanistic-based exposure and risk models, appraised with reported empirical data. Results implicated that exposure to smoke emitted from heavy incense burning may promote lung cancer risk.

There are limited data of pollutants emitted from incense burning in Thailand. Consequently, the main objectives of the research are to measure air pollutants $\left(\mathrm{PM}_{2.5}\right.$ and $\left.\mathrm{NO}_{2}\right)$ emitted from incense burning in shrines during special occasion and normal period to assess indoor air quality changes based on burning of incense.

\section{MATERIAL AND MethodS}

\section{A. Sampling Sites}

The sampling sites consisted of the famous shrines located in one of the most crowded areas in the city of Chiang Mai, namely Waroros Market. The first shrine is the older of the two shrines and was founded in 1876 by Chinese ancestors. The size of the building is approximately $8 \times 18 \mathrm{~m}^{2}$ and $4 \mathrm{~m}$ in height. The building is poorly ventilated as it was designed as almost a closed system of air-flow with only one door open for visitors. The second shrine has an area of approximately $12 \times 20 \mathrm{~m}^{2}$. The compound was contained within high walls ( $4 \mathrm{~m}$ height $)$. A worship room $\left(12 \times 6 \mathrm{~m}^{2}\right)$ is situated at one side of the area, while the other side is an open area. The ventilation system in the second shrine is better than the first one. It has 4 turbine ventilators on the roof of the worship room and its ceiling is open. This shrine is located near a narrow road with high traffic density, which included motorcycles and small diesel trucks (pick-ups), on a daily basis.

At the first shrine, each visitor would purchase 8 large incense sticks $(\sim 9 \mathrm{~mm}$ diameter, $\sim 48 \mathrm{~cm}$ long and $\sim 34 \mathrm{~cm}$ coated combustible part). After each individual ceremony, the burned incense sticks were not allowed to be kept inside the worship area, but were kept outside. At the second shrine, one visitor would purchase a package of 28 smaller incense sticks. Twenty-six of them were burned in the worship room and the rest were burned outdoors. The size of a single incense stick was much smaller than those at the first shrine. Each one had a diameter of $\sim 2.4 \mathrm{~mm}$, was $32 \mathrm{~cm}$ long and had a $21 \mathrm{~cm}$ coated combustible part.

The sampling was carried out at both shrines during special occasions and over normal periods (background value). The special occasions were those associated with the Chinese lunar calendar, such as Chinese New Year, the Chinese Ghost festival, a vegetarian festival, the moon festival, as well various other celebrations of the shrine that were considered.

\section{B. $\quad$ PM $_{2.5}$ Sampling}

Indoor $\mathrm{PM}_{2.5}$ samples were collected on Teflon fiber filters (2 $\mu \mathrm{m}$ PTFE, $46.2 \mathrm{~mm}$ diameter, Whatman's filter paper) using Minivol Air Samplers (Air metric, USA) at a flow rate of $5 \mathrm{~L} / \mathrm{min}$ for $8 \mathrm{hrs}(8 \mathrm{am}-4 \mathrm{pm})$ and 24 hours $(8 \mathrm{am}-8$ am). The filters were pre-weighed by a microbalance in a controlled room $\left(25.4 \pm 2.8{ }^{\circ} \mathrm{C}, 41.3 \pm 5.4 \% \mathrm{RH}\right)$. After the sampling, the filters were kept in aluminium foil plates inside a desicator for $48 \mathrm{~h}$ before being re-weighed and stored in a freezer $\left(-4.0^{\circ} \mathrm{C}\right)$ until analysis.

\section{C. $\mathrm{NO}_{2}$ Sampling}

The Indoor and outdoor $\mathrm{NO}_{2}$ levels were collected by lab made passive samplers [15] in order to estimate $\mathrm{NO}_{2}$ levels emitted from different sources. The major source of $\mathrm{NO}_{2}$ outdoors was traffic emissions, while the burning of incense was the primary indoor source. The sampler consists of a polypropylene (PP) diffusion tube $(7.70 \mathrm{~cm}$ length and 2.00 $\mathrm{cm}$ inter diameter) containing Whatman's GF/A filter paper impregnated with $50 \mu \mathrm{l}$ of $20 \%$ TEA. A set of the samplers (5 sampling tubes and 3 blank tubes) attached in a shelter were hung at $1.5-2.0 \mathrm{~m}$ above ground level for 8 and 24 
hours. After the sampling, the $\mathrm{NO}_{2}$ concentration was determined colorimetrically as nitrite $\left(\mathrm{NO}_{2}{ }^{-}\right)$. For extraction, $2 \mathrm{ml}$ of de-ionized water were added into the tube and stirred well for 15 minutes to allow the nitrite to dissolve in the water. One $\mathrm{ml}$ of the nitrite solution was mixed with $2 \mathrm{ml}$ Saltzman reagent. After extraction, the absorbance was measured by spectrophotometer (Jasco UV 530, Japan) at $540 \mathrm{~nm}$.

TABLE I: AVERAGE INDOOR PM ${ }_{2.5}$ CONCENTRATIONS AND NUMBER OF ViSITORS AT TwO SHRINES DURING SPECIAL OCCASIONS AND NORMAL

\begin{tabular}{|c|c|c|c|c|c|}
\hline \multicolumn{6}{|c|}{ PERIOD } \\
\hline \multirow{3}{*}{ Sampling periods } & & \multicolumn{2}{|c|}{$\mathrm{PM}_{2.5}$} & \multicolumn{2}{|c|}{ Number of visitor } \\
\hline & & $8 \mathrm{hrs}$ & $24 \mathrm{hrs}$ & $8 \mathrm{hrs}$ & $24 \mathrm{hrs}$ \\
\hline & & & & & \\
\hline \multicolumn{6}{|l|}{ Shrine 1} \\
\hline \multirow{3}{*}{$\begin{array}{l}\text { Chinese New Year } \\
\left(n=3^{*} \text { and } n=6^{* *}\right)\end{array}$} & $\operatorname{Max}$ & 603 & 450 & 547 & 961 \\
\hline & Min & 151 & 136 & 347 & 117 \\
\hline & Mean $( \pm \mathrm{SD})$ & $400 \pm 230^{\mathrm{b}}$ & $317 \pm 109^{b}$ & $456 \pm 101^{\mathrm{b}}$ & $454 \pm 294^{b}$ \\
\hline \multirow{3}{*}{$\begin{array}{l}\text { Other special occasions } \\
\left(n=7^{*} \text { and } n=8^{* *}\right)\end{array}$} & $\operatorname{Max}$ & 327 & 310 & 157 & 457 \\
\hline & Min & 159 & 84 & 19 & 78 \\
\hline & Mean $( \pm S D)$ & $230 \pm 66^{\mathrm{a}}$ & $178 \pm 81^{\mathrm{a}}$ & $70 \pm 46^{\mathrm{a}}$ & $175 \pm 123^{\mathrm{a}}$ \\
\hline \multirow{3}{*}{$\begin{array}{l}\text { Normal period } \\
(n=7)^{*}, * * *\end{array}$} & $\operatorname{Max}$ & 118 & 110 & 18 & 42 \\
\hline & Min & 44 & 34 & 5 & 8 \\
\hline & Mean $( \pm$ SD) & $82 \pm 25^{\mathrm{c}}$ & $53 \pm 26^{c}$ & $11 \pm 4^{\mathrm{c}}$ & $19 \pm 14^{\mathrm{c}}$ \\
\hline \multicolumn{6}{|l|}{ Shrine 2} \\
\hline \multirow{3}{*}{$\begin{array}{l}\text { Chinese New Year } \\
\left(n=3^{*} \text { and } n=6^{* *}\right)\end{array}$} & $\operatorname{Max}$ & 764 & 678 & 702 & 1,040 \\
\hline & Min & 471 & 194 & 126 & 161 \\
\hline & Mean $( \pm \mathrm{SD})$ & $625 \pm 147^{b}$ & $406 \pm 159^{b}$ & $390 \pm 291^{\mathrm{b}}$ & $631 \pm 319^{b}$ \\
\hline \multirow{3}{*}{$\begin{array}{l}\text { Other special occasions } \\
\left(n=11^{*} \text { and } n=8^{* *}\right)\end{array}$} & $\operatorname{Max}$ & 305 & 276 & 55 & 82 \\
\hline & Min & 99 & 73 & 10 & 17 \\
\hline & Mean $( \pm \mathrm{SD})$ & $184 \pm 81^{\mathrm{a}}$ & $133 \pm 71^{\mathrm{a}}$ & $23 \pm 13^{\mathrm{a}}$ & $42 \pm 23^{\mathrm{a}}$ \\
\hline \multirow{3}{*}{$\begin{array}{l}\text { Normal period } \\
\left(n=10^{*} \text { and } n=14^{* *}\right)\end{array}$} & Max & 158 & 75 & 22 & 26 \\
\hline & Min & 15 & 17 & 5 & 5 \\
\hline & Mean $( \pm \mathrm{SD})$ & $92 \pm 42^{c}$ & $50 \pm 20^{c}$ & $9 \pm 5^{\mathrm{c}}$ & $12 \pm 6^{\mathrm{c}}$ \\
\hline
\end{tabular}

${ }^{\mathrm{a}, \mathrm{b}, \mathrm{c}}=$ Significant difference $(p<0.05)$ among groups of sampling periods (vertical direction)

* the amount of samples for $8 \mathrm{hrs}$ and ** the amount of samples for $24 \mathrm{hrs}$

\section{RESULTS AND DISCUSSION}

\section{A. Concentrations of Indoor $P M_{2.5}$}

Table I shows the concentrations of $\mathrm{PM}_{2.5}$ measured indoors and the number of visitors at two shrines on special occasions (with the exclusion of Chinese New Year), as well as on Chinese New Year and the normal period (background value). The background values of 8 hours of indoor $\mathrm{PM}_{2.5}$ measuring ranged from $82 \pm 25 \mu \mathrm{g} / \mathrm{m}^{3}$ (shrine 1) to $92 \pm 42$ $\mu \mathrm{g} / \mathrm{m}^{3}$ (shrine2), while those of the 24-hour period were $50 \pm 20 \mu \mathrm{g} / \mathrm{m}^{3}$ (shrine 2) to $53 \pm 26 \mu \mathrm{g} / \mathrm{m}^{3}$ (shrine 1). The concentrations of PM2.5 at shrines 1 were slightly lower than those at shrine 2 . It might be because in case of the shrine 1 , burned incense sticks were not allowed to keep inside the shrine. Based on the results, the different architecture of the two shrines might not play a significant role for PM concentrations. Otherwise, if the number of visitors is the almost equal, the PM2.5 concentrations in the shrine 1 should be higher than the shrine 2 due to its poorer ventilation system. It was obvious that the mean PM2.5 concentrations measured during each occasion were significantly different.
Their concentrations in descending order were Chinese New Year $>$ other special occasions $>$ the normal period. This pattern was the same for both 8 and $24 \mathrm{hr}$ periods at the two shrines. The main reason for the high levels of pollutants found indoors was clearly the number of visitors, which was related with the amount of incense being burned. During Chinese New Year and on other special occasions, the $24 \mathrm{hr}$ mean values of $\mathrm{PM}_{2.5}$ concentrations collected from both shrines were 3-4 times higher than the National Ambient Air Quality Standard (NAAQS), USA $\left(65 \mu \mathrm{g} / \mathrm{m}^{3}\right)$. When comparing these values with other places, the $8 \mathrm{hr} \mathrm{PM}_{2.5}$ concentrations measured in this study during Chinese New Year $\left(400 \pm 230 \mu \mathrm{g} / \mathrm{m}^{3}\right.$ to $\left.625 \pm 147 \mu \mathrm{g} / \mathrm{m}^{3}\right)$ were higher than those found in a temple in Hong Kong $\left(360 \pm 23 \mu \mathrm{g} / \mathrm{m}^{3}\right)$ during $8 \mathrm{hrs}$ of exposure at the peak periods, which were measured on either the first or the fifteenth day of each month of the Chinese lunar calendar [16].

\section{B. Indoor and Outdoor of $\mathrm{NO}_{2}$ Concentrations}

The average concentrations of $\mathrm{NO}_{2}$ that were measured both indoors and outdoors at the two shrines during Chinese New Year, on other special occasions and during the normal 
periods are shown in Table II. It was found that the concentrations of $\mathrm{NO}_{2}$ that were measured indoors were slightly higher than those that were measured outdoors, but there was no significant difference among their average concentrations. The indoor $\mathrm{NO}_{2}$ concentrations measured during Chinese New Year were higher than those measured during the special occasions for all cases ( 8 and 24 hours at both shrines). However, the values were not significantly different $(p>0.05)$. The average concentrations measured during both designated periods from both shrines were however significantly higher than the normal period.

The outdoor $\mathrm{NO}_{2}$ concentrations measured on special occasions and those that were measured normal periods were not significantly different, but were significantly lower than those measured on Chinese New Year $(p<0.05)$. The highest indoor and outdoor $\mathrm{NO}_{2}$ concentrations $(8 \mathrm{hrs})$ were found during Chinese New Year $(55.3 \pm 0.0$ and $48.3 \pm 5.8$ ppbv, respectively) at shrine 1 , and these figures were related to the number of visitors and consequently the amount of incensed burned. However, all the indoor $\mathrm{NO}_{2}$ levels did not exceed those that were measured at the Hong Kong - IAQO 8 hrs-average good class concentration of $\mathrm{NO}_{2}(<80 \mathrm{ppbv})$.
The information on the indoor/outdoor $(\mathrm{I} / \mathrm{O})$ ratios of $\mathrm{NO}_{2}$ concentrations is important. The I/O ratio was generally found to be greater than 1 , which shows that the exposure of $\mathrm{NO}_{2}$ values can be higher indoors when compared with the outdoor area [17]. The average $\mathrm{I} / \mathrm{O}$ ratio for $\mathrm{NO}_{2}$ concentrations (Table II) illustrates that the $\mathrm{I} / \mathrm{O}$ ratio in the shrine 2 was greater than that of shrine 1 , due to a greater amount of incense being burned. The $\mathrm{I} / \mathrm{O}$ ratio of $\mathrm{NO}_{2}$ recorded during the Chinese New Year at shrine 1 was less than 1 (outdoors > indoors). This is probably due to shrine 1 's rule, which states that: "burned incense sticks are not allowed to kept inside the shrine". For shrine 2, the I/O ratio was also less than 1 . The reason for this might be different from that of the first shrine. The outdoor $\mathrm{NO}_{2}$ level was higher than the indoor level due to high traffic density at the roads nearby the shrine [18], [19]. The highest I/O ratio over $8 \mathrm{hrs}$ was found during Chinese New Year, due to the large amount of incense being burned in shrine 2. The mean $\mathrm{I} / \mathrm{O}$ ratio of $\mathrm{NO}_{2}$ in this study was $1.2 \pm 0.1$, which was lower than the mean ratio from medieval churches in Cyprus (1.97) [20]. This was probably related with the amount of incense being burned indoors.

TABLE II: CONCENTRATIONS OF INDOOR AND OUTDOOR NITROGEN DIOXIDE

\begin{tabular}{|c|c|c|c|c|c|c|c|}
\hline \multirow{3}{*}{ Sampling periods } & & \multicolumn{6}{|c|}{$\mathrm{NO}_{2}$ concentrations (ppbv) } \\
\hline & & \multicolumn{3}{|c|}{$8 \mathrm{hrs}$} & \multicolumn{3}{|c|}{$24 \mathrm{hrs}$} \\
\hline & & Indoor & Outdoor & $\begin{array}{r}\mathrm{I} / \mathrm{O} \\
\text { ratio }\end{array}$ & Indoor & Outdoor & $\begin{array}{r}\mathrm{I} / \mathrm{O} \\
\text { ratio } \\
\end{array}$ \\
\hline \multicolumn{8}{|l|}{ Shrine 1} \\
\hline \multirow{2}{*}{$\begin{array}{l}\text { Chinese New Year } \\
\left(n=3^{*} \text { and } n=6^{* *}\right)\end{array}$} & $\operatorname{Max}$ & 55.3 & 54.6 & & 54.3 & 75.0 & \\
\hline & Mean $( \pm \mathrm{SD})$ & $55.3 \pm 0.0^{\mathrm{a}, \mathrm{A}}$ & $48.3 \pm 5.8^{\mathrm{b}, \mathrm{A}}$ & 1.1 & $40.4 \pm 8.9^{\mathrm{a}, \mathrm{A}}$ & $42.8 \pm 18.1^{\mathrm{b}, \mathrm{A}}$ & 0.9 \\
\hline \multirow{3}{*}{$\begin{array}{l}\text { Other Special occasions } \\
\left(n=7^{*} \text { and } n=8^{* *}\right)\end{array}$} & Max & 58.9 & 54.6 & & 51 & 33.8 & \\
\hline & Min & 31.1 & 15.8 & & 28.9 & 16.2 & \\
\hline & Mean $( \pm \mathrm{SD})$ & $42.9 \pm 10.5^{\mathrm{a}, \mathrm{A}}$ & $29.9 \pm 14.7^{\mathrm{a}, \mathrm{A}}$ & 1.4 & $34.1 \pm 7.3^{\mathrm{a}, \mathrm{A}}$ & $27.7 \pm 5.4^{\mathrm{a}, \mathrm{A}}$ & 1.2 \\
\hline \multirow{3}{*}{$\begin{array}{l}\text { Normal period } \\
(n=7)^{*, * *}\end{array}$} & $\operatorname{Max}$ & 39.5 & 49.1 & & 29.9 & 27.8 & \\
\hline & Min & 23.4 & 13.2 & & 14.4 & 12.4 & \\
\hline & Mean $( \pm S D)$ & $32.2 \pm 5.8^{\mathrm{b}, \mathrm{A}}$ & $26.9 \pm 9.2^{\mathrm{a}, \mathrm{B}}$ & 1.2 & $23.1 \pm 5.7^{\mathrm{b}, \mathrm{A}}$ & $20.0 \pm 4.8^{\mathrm{a}, \mathrm{A}}$ & 1.2 \\
\hline \multicolumn{8}{|l|}{ Shrine 2} \\
\hline \multirow{3}{*}{$\begin{array}{l}\text { Chinese New Year } \\
\left(n=3^{*} \text { and } n=6^{* *}\right)\end{array}$} & Max & 63.6 & 32.9 & & 54.7 & 43.4 & \\
\hline & Min & 41.6 & 15.6 & & 31.6 & 27.4 & \\
\hline & Mean $( \pm \mathrm{SD})$ & $50.1 \pm 11.8^{\mathrm{a}, \mathrm{A}}$ & $24.3 \pm 8.7^{\mathrm{b}, \mathrm{B}}$ & 2.1 & $41.4 \pm 8.6^{\mathrm{a}, \mathrm{A}}$ & $32.8 \pm 5.9^{\mathrm{b}, \mathrm{A}}$ & 1.3 \\
\hline \multirow{3}{*}{$\begin{array}{l}\text { Other Special occasions } \\
\left(n=11^{*} \text { and } n=8^{* *}\right)\end{array}$} & Max & 54.0 & 57.1 & & 45.2 & 51.7 & \\
\hline & Min & 29.6 & 34.5 & & 27 & 32.9 & \\
\hline & Mean $( \pm \mathrm{SD})$ & $41.4 \pm 7.4^{\mathrm{a}, \mathrm{A}}$ & $42.6 \pm 6.3^{\mathrm{a}, \mathrm{A}}$ & 1.0 & $34.0 \pm 6.8^{\mathrm{a}, \mathrm{A}}$ & $41.8 \pm 7.4^{\mathrm{a}, \mathrm{B}}$ & 0.8 \\
\hline \multirow{3}{*}{$\begin{array}{l}\text { Normal period } \\
\left(n=10^{*} \text { and } n=14^{* *}\right)\end{array}$} & $\operatorname{Max}$ & 45.7 & 63.7 & & 33.3 & 43.4 & \\
\hline & Min & 25.4 & 21.4 & & 15.5 & 23.0 & \\
\hline & Mean $( \pm S D)$ & $33.4 \pm 6.9^{\mathrm{b}, \mathrm{A}}$ & $38.6 \pm 11.7^{\mathrm{a}, \mathrm{A}}$ & 0.9 & $23.1 \pm 5.7^{\mathrm{b}, \mathrm{A}}$ & $30.6 \pm 6.3^{b, B}$ & 0.8 \\
\hline
\end{tabular}

\section{Pearson's Correlations between Pollutants $\left(\mathrm{NO}_{2}\right.$ and $P M_{2.5}$ ) and Number of Visitors}

The correlation of each pair of parameters was examined by Pearson's correlation. The method is to take a collection of paired sample data and reflects the dynamic quality of the relationship between the two variables. The correlation coefficient of sample measures the strength of the linear relationship that exists within a sample of $n$ bivariate data. 
The value of this descriptive statistic ranges between -1 and +1 . The strong relationship is bigger number mean better prediction [21], [22].

The results found that correlations between $\mathrm{PM}_{2.5}$ and $\mathrm{NO}_{2}$ concentrations were relatively strong $(r=0.580-0.779)$, due to the relationship to the burning of incense. However, the correlations between $\mathrm{PM}_{2.5}$ levels and the number of visitors $(r=0.812-0.884)$ were higher than those between the $\mathrm{NO}_{2}$ concentrations and the number of visitors $(r=0.581-0.736)$. The results obtained also indicated that the higher number of visitors was associated with the greater amount of incense being burned, resulting in higher pollutant concentrations indoors.

\section{CONCLUSION}

Concentrations of specific indoor pollutants, including $\mathrm{PM}_{2.5}$ and $\mathrm{NO}_{2}$, were found to be directly correlated with the amount of incense being burned at the location. It was clearly seen that levels of those pollutants were significantly higher on special occasions than during the normal period. The concentrations, in particular $\mathrm{PM}_{2.5}$, were higher than the standard values regulated by various organizations concerning air quality and health. This is based on the fact that bad indoor air quality significantly affects human health. The solutions involve the improvement of the ventilation systems in the warship rooms and a decrease in the amount of incense being burned by each visitor.

\section{ACKNOWLEDGMENT}

Financial support from the Center of Excellence on Environmental Health and Toxicology (EHT), the National Research University (NRU), Chiang Mai University and the Graduate School of Chiang Mai University are gratefully acknowledged.

\section{REFERENCES}

[1] M. Fierro. (August, 2000). Particulate matter. [Online]. pp. 1-11. Available: http://www.Air_uplate/particulate matter-singspace. html

[2] T. C. Lin, G. Krishnaswamy, and D. S. Chi, "Incense smoke: clinical, structural and molecular effects on airway disease," Clinical and Molecular Allergy, 2008, vol. 6, no. 3, pp. 1-9.

[3] C. A. Pope, R. T. Burnett, M. J. Thun, E. E. Calle, D. Krewski, and K. Ito, "Lung cancer, cardiopulmonary mortality and long-term exposure to fine particulate air pollution," Journal of American Medical Association, 2002, vol. 287, pp. 1132-114,

[4] World Health Organization (WHO), WHO Air Quality Guidelines for Particulate Matter, Ozone, Nitrogen Dioxide and Sulfur Dioxide, Geneva, Switzerland, 2005, pp. 1-20.

[5] C. R. Estrellan and F. Iino, "Toxic emission from open burning," Chemosphere, vol. 80, pp. 193-207, 2010.

[6] S. C. Lee and B. Wang, "Characteristics of emissions of air pollutants from burning of incense in a large environmental chamber," Atmospheric Environment, 2004, vol. 38, pp. 941-951.

[7] S. W. See and R. Balasubramanian, "Characterization of fine particle emissions from incense burning," Building and Environment, 2011, vol. 46, pp. 1074-1080.

[8] J. J. Jetter, Z. Guo, J. A. McBrian, and M. R. Flynn, "Characterization of emissions from burning incense," Science of the Total Environment. vol. 295, pp. 51-67, 2002.
[9] G. C. Fang, C. N. Chang, Y. S. Wu, C. J. Yang, S. C. Chang, and I. L. Yang, "Suspended particulate variations and mass size distributions of incense burning at Tzu Yun Yen temple in Taiwan, Taichung," Science of the Total Environment, vol. 299, pp. 79-87, 2002.

[10] T. C. Lin, F. H. Chang, J. H. Hsieh, H. R. Chao, and M. R. Chao, "Environmental exposure to polycyclic aromatic hydrocarbons and total suspended particulates in a Taiwanese temple," Bulletin of Environmental contamination and Toxicology, 2001, vol. 67, pp. 332-338.

[11] T. T. Yang, T. S. Lin, and M. Chang, "Characteristics of Emissions of Volatile Organic Compounds from Smoldering Incense," Bulletin of Environmental Contamination and Toxicology, vol. 78, pp. 308-313, 2007.

[12] K. C. Chiang and C. M. Liao, "Heavy incense burning in temples promotes exposure risk from airborne PMs and carcinogenic PAHs," The Science of the Total Environment, vol. 372, pp. 64-75, 2006.

[13] P. Navasumrit, M. Arayasiri, O. M. T. Hiang, M. Leechawengwongs, J. Promvijit, S. Choonvisase, S. Chantchaemsai, N. Nakngam, C. Mahidol, and M. Ruchirawat, "Potential health effects of exposure to carcinogenic compounds in incense smoke in temple workers," Chemico-Biological Interactions, 2008, vol. 173, pp. 19-31.

[14] C. Y. Kuo, Y. H. Yang, M. R. Chao, and C. W. Hu, "The exposure of temple workers to polycyclic aromatic hydrocarbons," Science of the Total Environment, vol. 401, pp. 44-50, 2008.

[15] S. Bootdee, P. Chalemrom, and S. Chantara, "Validation and field application of tailor-made nitrogen dioxide passive sampler," International Journal of Environmental Science and Technology, vol. 9, pp. 515-526, 2012.

[16] B. Wang, S. C. Lee, K. F. Ho, and Y. M. Kang, "Characteristics of emissions of air pollutants from burning of incense in temples, Hong Kong," The Science of the Total Environment, vol. 377, pp. 52-60, 2007.

[17] C. Monn, A. Fuchs, D. Hogger, M. Junker, D. Kogelschatz, N. Roth, and H.-U. Wanner, "Particulate matter less than $10 \mu \mathrm{m}\left(\mathrm{PM}_{10}\right)$ and Fine particles less than $2.5 \mu \mathrm{m}\left(\mathrm{PM}_{2.5}\right)$ : relationships between indoor, outdoor and personal concentrations," The Science of the Total Environment, vol. 208, pp. 15-21, 1997.

[18] S. S. Ahmad, P. Biiker, L. Emberson, and R. Shabbir, "Monitoring nitrogen dioxide levels in urban areas in Rawalpindi, Pakistan," Water Air and Soil pollution, 2011, vol. 220, no. 10, pp. 141-150.

[19] A. A. Salem, A. A. Soliman, and I. A. EI-Haty, "Determination of Nitrogen dioxide, sulfur dioxide, ozone and ammonia in ambient air using the passive sampling method associated with ion chromatographic and potentionmetric analyses," Air Quality, Atmophere and Health, 2009, vol. 2, pp. 133-145.

[20] G. Loupa and S. R. Chao, "Air pollutant emission rates and concentrations in medieval churches," Journal of Atmospheric Chemistry, vol. 60, pp. 169-187, 2008

[21] M. F. Triola, Elemetary Statistics, $4^{\text {th }}$ ed. Addisn Wesly longman, U.S.A., 2000, pp. 506-509.

[22] C. Hinrichs, Minitab Handbook, $14^{\text {th }}$ ed. Thomson learning Inc. U.S.A., 2005, pp. 313-134.

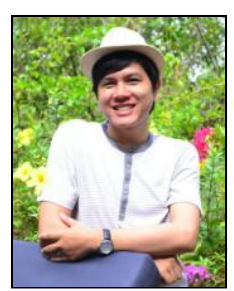

Susira Bootdee was born in Chiang Rai Province, Thailand in 1983. His educational background was a bachelor degree in Agricultural program from Mae Jo University (MJU), Thailand in 2006. His master degree was in Environmental Science from CMU, Thailand in 2009. Now, He is Ph.D. student of Environmental Science Program at CMU. His research contributions are in the field of environmental analytical chemistry. He has been in the air quality monitoring and assessment of air pollutants sources including sampling and analysis of nitrogen dioxide $\left(\mathrm{NO}_{2}\right)$ in ambient air and PAHs-bound $\mathrm{PM}_{2.5}$ indoor air quality. He is interested with effect of indoor pollution to human health.

Mr. Susira is a member of Environmental Chemistry Research Laboratory (ECRL) since 2007 and a member of student. His personal hobbies are playing badminton, going to temple with made merit and meditation. 